\title{
Zawód: reporter. Filmowy dyskurs o dziennikarstwie na lekcjach języka polskiego
}

\section{Profession: reporter. Film discourse on journalism during Polish language lessons}

\author{
Witold Bobiński \\ Uniwersytet Jagielloński, Kraków \\ ORCID: 0000-0001-5480-051
}

\begin{abstract}
The article discusses media and journalism ethics portrayed in the movies from the 1970's onwards. First the text examines the role of media and journalism in Western democracies established on the values of freedom and equality. Media - according to works of John Rawls and Jurgen Habermas - constitutes the fourth pillar of democracy (the others are: legislature, executive and judiciary). Media independence has been an ever-present issue in cinematography. The article offers didactic tools to analyze five political dramas (All the President's Men, Wag the Dog, Spotlight, The Post, Mr Jones) and one psychological drama/thriller (The Passenger). Three different perspectives (plot analysis, formal analysis, „great metaphore”) can be used in secondary schools to highlight the role of media and independent journalism.

Key words: independent journalism, independent media, media ethics, ethics of journalism, liberal democracy, liberal equality, political drama, film education, film analisys, secondary humanities
\end{abstract}

Streszczenie: Artykuł dotyczy dydaktycznego wykorzystania filmów fabularnych związanych z problematyką niezależnego dziennikarstwa i etosu dziennikarskiego. We wstępnej części tekstu autor przybliża wspomnianą problematykę, odwołując się do współczesnych filozofów, klasyków myśli liberalnej i orędowników porządku demokratycznego wspartego na wartościach równości i wolności (Habermas, Rawls). Komponentem tak pojmowanego systemu demokracji parlamentarnej, i jednym z jej filarów, są wolne media, które umożliwiają funkcjonowanie niezależnego, a przy tym zaangażowanego w życie publiczne, dziennikarstwa. Problematyka ta znalazła odzwierciedlenie w niektórych filmach fabularnych zaliczanych do gatunku określanego jako dramat polityczny czy dramat społeczny. $\mathrm{W}$ artykule omówiono wybrane pozycje tego gatunku z ostatnich 45 lat, poczynając od Wszystkich ludzi prezydenta Alana Pakuli. Autor proponuje dydaktyczne wykorzystanie filmów, spoglądając na nie z trzech perspektyw: fabuły (świata przedstawionego), formy (języka filmu) i tzw. „wielkiej metafory”. Propozycje adresowane są nie tylko do polonistów, lecz także do innych nauczycieli, których działania lokują się w obszarze szkolnego kształcenia humanistycznego. 
Słowa kluczowe: wolne media, niezależne dziennikarstwo, etos dziennikarski, parlamentaryzm, demokracja liberalna, analiza filmu, dramat polityczny, edukacja filmowa, edukacja humanistyczna

Współczesna refleksja o edukacji mocno podkreśla konieczność otwarcia szkoły na środowisko, w którym funkcjonuje, na różne aspekty rzeczywistości. Przeświadczenie to bierze się z wizji powszechnego nauczania, które w swym fundamentalnym wymiarze służy upodmiotowieniu człowieka i wdrażaniu go do dojrzałego życia wśród innych. Nieodłącznym składnikiem współczesności, w której istnieje szkoła, są media, które tyleż odzwierciedlają rzeczywistość, ile są jej nieustannym, wszechobecnym kreatorem. Są nieusuwalnym i przemożnym uczestnikiem naszego życia. Inicjowanie dojrzałej, krytycznej refleksji o mediach i ich związku z różnymi wymiarami naszej egzystencji powinno więc być zadaniem szkoły. W niniejszym artykule proponuję kilka sposobów podejmowania tego tematu z wykorzystaniem filmów fabularnych, w których zagadnienie mediów i pracy dziennikarza stanowią kwestię kluczową.

\section{Sprawiedliwość, czyli mam prawo wiedzieć}

Niezależnie dziennikarstwo, niepodatne na polityczne naciski i wolne od cenzury, jest jednym z fundamentów demokracji. Wpisuje się bowiem w sferę podstawowych praw człowieka i obywatela, wśród których jednym $\mathrm{z}$ istotniejszych jest prawo do rzetelnej i wiarygodnej informacji o otaczającym świecie - o osobach, zdarzeniach, zjawiskach, wypowiedziach. Filozoficznie wyrasta ono z prawa do wolności słowa (to zaś - z prawa do wolności myśli) i jako takie - jest jednym z komponentów idei sprawiedliwości społecznej, której nowoczesny wyraz dał klasyk myśli liberalnej opartej na fundamencie równości - John Rawls. Wedle jego pierwszej zasady sprawiedliwości społecznej „każda osoba ma mieć równe prawo do jak najszerszego systemu równych podstawowych wolności, możliwego do pogodzenia z podobnym systemem wolności dla innych" (Rawls 1994) ${ }^{1}$. Oznacza to, między innymi, prawo do wolności sumienia, myśli, zgromadzeń, zrzeszeń, działania społecznego i politycznego, a także nienaruszalności osoby i rządów prawa. Gwarantem owych wolności (a więc instancją, która chroni prawa do nich), obejmujących również wolność dostępu do informacji, ma być - wedle Rawlsa - państwo. Konieczność ochrony owego prawa do informacji, jako podstawowego prawa obywateli, wpisana jest w najważniejsze deklaracje i akty prawne Komisji Europejskiej i Parlamentu Europejskiegooraz w ustawy zasadnicze poszczególnych państw członkowskich (jest zapisana również Konstytucji RP). Można by więc powiedzieć,

${ }^{1}$ Mimo iż spektakularne dzieła Rawlsa łączy się z liberalizmem, jego koncepcja daleka jest od bezdusznego utylitaryzmu czy bałwochwalczego stosunku do produktywności i efektywności gospodarczej. Myśl Rawlsa wyrasta z tradycji umowy społecznej, zaś ideę maksymalnej wolności jednostki wiąże on w sposób nieodwołalny z postulatem równości praw obywatelskich i niezgodą na podtrzymywanie, a tym bardziej powiększanie nierówności społecznych. 
że w cywilizowanym świecie prawo do informacji uznaje się za oczywiste i nie podlegające dyskusji (pomijam w tym miejscu rozważań politologiczne i filozoficzne debaty nad granicami wolności słowa i konsekwencjami, jakie często przypisuje się niczym nieograniczonej swobodzie kolportowania informacji; jest to temat frapujący i obrosły obszerną literaturą).

Hasła wolności słowa i prawa do informacji, które wszak wszyscy uznamy za słuszne i zasadne, niejako milcząco zakładają, iż krążące w przestrzeni publicznej słowa i informacje są rzetelne, wiarygodne - po prostu prawdziwe. Na takie bowiem słowa i informacje czekamy i jesteśmy otwarci, z takimi właśnie - a nie z kłamstwami i półprawdami - gotowi jesteśmy kooperować: wykorzystywać je, opowiadać się względem nich, odpowiadać na nie. Skoro zaś mowa o prawdzie w życiu publicznym, to zarówno refleksja filozoficzna, jak i doświadczenie potoczne mówią nam, iż jest to $\mathrm{w}$ istocie

\section{domena etyki,}

tej jednostkowej i tej publicznej. Nieuchronnie dochodzimy w tym skróconym wywodzie do pojęć takich, jak etyka komunikacji, mediów, etyka dziennikarska, do których niejednokrotnie w tym tekście będziemy wracać. Odruchowo łączymy z nimi kategorię prawdy, a za jej antonimy uznajemy kłamstwo, dezinformację, manipulację i - na prawach odległej antytetycznej relacji - cenzurę. Dlaczego jednak ci, którzy profesjonalnie zajmują się informowaniem, obowiązani są do posługiwania się prawdą w życiu publicznym? Nie muszą wszak brać sobie do serca przykazania, które zakazuje składania „fałszywego świadectwa”. Niewątpliwie przekonanie o zasadności i konieczności posługiwania się prawdą w komunikacji społecznej brać się powinno z szacunku dla drugiego człowieka, dla Innego. Przeświadczenie to odnajdujemy w myśli jednego z najbardziej wnikliwych obserwatorów i analityków współczesności, Jurgena Habermasa, „filozofa pozostającego w służbie demokracji parlamentarnej" (Wróbel 2016).

Habermas mówi: musisz zróżnicować swoje życie, musisz zrozumieć, że jest ono oparte na życiu wielu innych. Musisz żyć, pamiętając o klęsce innych, pamiętając, że twoje życie jest rzadko tylko twoje. Musisz żyć, uwzględniając życie Innego (Wróbel 2016).

Obok etycznego, pojawia się tu zatem także

\section{argument pragmatyczny:}

jeśli zależy nam na choćby znośnym, a może wręcz satysfakcjonującym, uporządkowaniu życia ludzi w małych i dużych społecznościach, to dezinformacja i fałszowanie obrazu rzeczywistości zdają się mocno przeciwskuteczne, wprowadzają chaos i poczucie krzywdy. Myśl Habermasa jest przeniknięta przekonaniem o możliwości, ale zarazem konieczności „ponownego oświecenia”, a więc swoistego odnowienia (re-konstrukcji, 
re-aranżacji) przestrzeni społecznej i zasad debaty publicznej. Filozofa niepokoją współczesne deformacje systemów politycznych prowadzące do wykształcenia formuł o charakterze postdemokracji. Idea Habermasa jest w szczególny sposób konserwatywna, gdyż zakłada prawdziwy powrót do fundamentów demokracji parlamentarnej: „istnienie parlamentarnych urządzeń, trójpodział władzy, społeczna kontrola, niezależność instytucji prawnych, wolne media to główne składniki jego wiary" (Wróbel 2016). Wymienione tu filary ustrojowe systemów demokratycznych zasadzają się tyleż na fundamentach etycznych, ile na racjonalnej, wspartej na doświadczeniu, wizji pragmatyki życia społecznego, przy czym etyka i pragmatyka pozostają tu w związku o charakterze sprzężenia zwrotnego, tworzą dynamiczne continuum, które jest $w$ istocie jedynym efektywnym mechanizmem regulującym życie [w] zbiorowości. Mówi o tym niemiecki filozof:

W codziennych rutynowych działaniach podmioty zakładają wzajemnie, że działają w sposób poczytalny i mówią o tych samych przedmiotach; że myślą to, co mówią, że dotrzymają obietnic, które składają; że ich twierdzenia są prawdziwe; że normy, których obowiązywanie milcząco przyjmują, są faktycznie prawomocne itd. (Foessel 2016).

Założenia, które niemal odruchowo przyjmujemy w kontaktach z innymi, stanowią też podstawę naszego stosunku do mediów - chcemy wierzyć, że ci, którzy przekazują informacje, nie chcą nas okłamywać, wprowadzać w błąd lub wykorzystywać dla korzyści własnych czy interesów kogoś innego. Tak bowiem pojmujemy sens istnienia prasy, radia, telewizji, mediów internetowych - jako kanałów przekazywania informacji prawdziwych i źródeł pomagających nam w poznaniu i zrozumieniu rzeczywistości. Zakładamy, że takie jest - najogólniej - zadanie, a może nawet powołanie mediów, by nie rzec: ich misja. Taką wizję (o)środków masowej informacji spotkamy, oczywiście, u Habermasa, którego myśl relacjonuje Jan Pleszczyński, stwierdzając, iż dziennikarstwo (określane przez niego jako deontologiczne²) jest „zawodem zaufania publicznego, służbą i misją" (Pleszczyński 2015, 110). Autor wyraża przeświadczenie, iż „przynajmniej w sferze intencji media deontologiczne zawsze mają na uwadze

\section{dobro wspólne i społeczeństwo obywatelskie"}

(Pleszczyński 2015, 111).

To właśnie ten aspekt ich funkcjonowania (i idei stojącej u podstaw ich powoływania) odróżnia je (przynajmniej w teorii) od komercyjnych mediów rozrywkowych, które dostarczają programów obliczonych na utrzymywanie odbiorców w dobrym samopoczuciu, zaspokajanie potrzeb odpoczynku, zabawy itp. Trzeba dodać, że media informacyjne zobowiązane

${ }^{2}$ Pojęcie „deontologiczny” możemy rozumieć jako: 'działający w zgodzie z obowiązkiem moralnym' lub też: 'zobowiązany do kierowania się nakazami moralnymi'. Deontologia bowiem to teoria etyczna, w myśl której - w dużym uproszczeniu - o wartości czynów nie decyduje ich użyteczność czy skuteczność, lecz przypisana im wartość mierzona m.in. intencjami, motywacjami, poszanowaniem wartości. 
są (w kontekście ich społecznej roli w państwach demokratycznych) do zachowywania wysokich standardów etycznych niezależnie od tego, czy są publiczne (państwowe, co nie oznacza: rządowe albo partyjne), czy prywatne, choć nieodłącznym i kluczowym aspektem działania tych drugich jest opłacalność ekonomiczna. To ona właśnie definiuje całkowicie formaty komercyjnych mediów rozrywkowych, co sprawia, że ich właściciele i nadawcy odpowiadają głównie (bądź jedynie) na najbardziej masowe, powszechne potrzeby i gusta. Niestety, upodobaniom szerokich rzesz odbiorców ulegają także media informacyjne, zarówno te prywatne, jak i publiczne, przez co „przestają one pełnić właściwe im funkcje i tracą niezależność" (Pleszczyński 2015, 111). Według Habermasa niezależne, odpowiedzialne dziennikarstwo to misja, która często wymaga przeciwstawienia się masowym przekonaniom czy upodobaniom (a także grupom interesów). Media informacyjne mają ogromny wpływ na odbiorców i kiedy pozostają na usługach pieniądza (dochodowość) bądź jednej tylko opcji politycznej, podkopują demokratyczną sferę publiczną. Jakim zatem wartościom mieliby być wierni dziennikarze, aby demokracji nie kruszyć, lecz ją wzmacniać? Aby - zaryzykujmy wielkie słowa - zmieniać świat na lepsze?

Niewątpliwie powinni kierować się odpowiedzialnością, ale ma to być

\section{odpowiedzialność wobec kogo?}

W cytowanej wyżej rozprawie Jan Pleszczyński wymienia kilka rodzajów obowiązków dziennikarzy - obowiązki wobec samego siebie, reklamodawców, pracodawcy, kolegów z branży, społeczeństwa (Pleszczyński 2015, 113). Jak pośród tych wszystkich zobowiązań i aspektów odpowiedzialności (przed samym sobą, swoim sumieniem, redakcją, odbiorcami) zachować niezależność? Kto lub co jest tą nadrzędną instancją, wobec której dziennikarki i dziennikarze powinni się w pierwszej kolejności zachowywać lojalnie? Ten niełatwy problem staje się nieco prostszy, gdy zmodyfikujemy pytanie: dla kogo, przede wszystkim, wykonuje swoje zajęcie dziennikarz? Sens jego istnieniu nadają odbiorcy, ale niewątpliwie poczucie sensu (satysfakcja, zadowolenie z pracy) jest (powinno być) udziałem samego dziennikarza. To odbiorcy i dziennikarskie „ja” stają się głównymi arbitrami w ocenie tego, co robią ci, którzy informują nas o świecie i komentują rzeczywistość. Sieć zależności i uwikłań dziennikarzy jest jednak, jak już wiemy, dużo gęstsza. Autor Etyki dziennikarskiej... cytuje bardzo trafny w tym kontekście fragment wypowiedzi Ryszarda Kapuścińskiego:

Ideałem jest oczywiście całkowita niezależność, lecz życie dalekie jest od ideału. Dziennikarz podlega wielu presjom, by pisał w sposób, w jaki chce pracodawca. Nasz zawód to ciągła walka pomiędzy marzeniami, pragnieniem niezależności a rzeczywistymi sytuacjami, które zmuszają nas do respektowania interesów, poglądów i oczekiwań naszego wydawcy. 
W krajach, w których istnieje cenzura, walczy się o to, żeby w możliwie największym stopniu wyrazić to, co się pragnie. W krajach, w których panuje wolność słowa, dziennikarza ograniczają interesy dziennika, dla którego pracuje. W wielu przypadkach dziennikarz, zwłaszcza młody, musi iść na daleko idące kompromisy i uciekać się do wyrafinowanej strategii, żeby uniknąć bezpośredniego starcia. Ale nie zawsze to jest możliwe i z tego właśnie powodu dochodzi do tylu prześladowań. Prześladowania te niewątpliwie różnią się od znanych skądinąd gwałtownych metod - przybierają formę zwolnień, faktycznego odsunięcia na margines życia zawodowego, groźby natury ekonomicznej. Ogólnie rzecz biorąc, jest to zawód, który wymaga ciągłej walki i czujności (Kapuściński 2003, 36-37).

Jeśli dziennikarstwo ma być rzetelne, uczciwe, wiarygodne, musi pozostać niezależne, niepodatne na naciski pojedynczych osób czy grup. Wtedy służy budowaniu dobra wspólnego (np. demokratycznego systemu organizacji życia społecznego), nie zaś tylko jednostkowego czy grupowego. Najwyższym standardom powinni hołdować nadawcy publiczni, ale także właściciele prywatnych tytułów prasowych, rozgłośni, stacji telewizyjnych czy portali informacyjnych. Pozostając w służbie dobra wspólnego, powinni w pierwszym rzędzie wystrzegać się wyrządzania krzywdy, prowokowania cierpienia, wprowadzania niezgody i nienawiści w życie publiczne. Encyklopedyczne czy słownikowe ujęcia etyki dziennikarskiej idą nawet dalej:

Etyka dziennikarska, postawa charakteryzująca się dążeniem do prawdy i adekwatności; bezstronnością i uczciwością, szacunkiem dla prywatności innych, niezależnością od wpływu ze strony grup interesów; szacunkiem dla prawa; respektowaniem dobrych obyczajów i dobrego smaku (Skrzypczak 1999, 133).

Walery Pisarek za etykę dziennikarską uznaje „ogół ocen, norm, zasad i ideałów określających poglądy, zachowania i działania uważane za właściwe, dobre, uzasadnione moralnie w pracy dziennikarzy i funkcjonowaniu mediów” (Pisarek 2006, 53). Warto dodać, że polscy dziennikarze, wydawcy, producenci i nadawcy w uchwalonej w 1995 roku Karcie Etyki Mediów uznali, że w swojej pracy będą kierować się zasadami:

- prawdy;

- obiektywizmu;

- oddzielania informacji od komentarza;

- uczciwości;

- $\quad$ szacunku i tolerancji;

- pierwszeństwa dobra odbiorcy;

- wolności i odpowiedzialności.

Czy w taki właśnie sposób działają media, z których codziennie korzystamy? Każdy i każda z nas potrafi i powinien / powinna sformułować odpowiedź na to pytanie. Odpowiedź ta bowiem nie dotyczy tylko mediów, ale też nas samych - naszych kompetencji oceny rzeczywistości, sposobu traktowania nas przez uczestników życia publicznego, naszego komfortu i satysfakcji z uczestnictwa w życiu społeczności.

Polonistyka. Innowacje

Numer 12, 2020 


\section{Sztuka życia wśród ludzi -}

tymi słowami, za księdzem Józefem Tischnerem, określił rzetelne dziennikarstwo Jan Pleszczyński. Ta skrótowa, syntetyczna definicja streszcza sens pracy dziennikarza i kształtujące ją uwarunkowania do formuły, pod którą podpisać moglibyśmy się wszyscy. Bo też zasady etyki dziennikarskiej bliskie są - po prostu - tym normom, które uznajemy za słuszne i potrzebne w codziennym życiu, i których chcielibyśmy wymagać od innych. Elementem owego codziennego życia od dawna pozostaje również szkoła, i kategoria „sztuki życia wśród ludzi” jest jednym z kluczowych atrybutów, jaki szkole przypisuje współczesna refleksja o edukacji.

Ujęcie sprawiedliwości Johna Rawlsa oraz rozpoznania i tezy na temat demokracji Jurgena Habermasa, trafnie opisujące rzeczywistość, naznaczoną wzajemnymi uwikłaniami etyki i polityki, mogłyby stanowić credo współczesnej filozofii edukacji. Podkreśla ona bowiem związki szkoły ze światem, określając szkołę jako światocentryczną (world-centered). To określenie znajduje swoje rozwinięcie w myśli holenderskiego filozofa Gerta J.J. Biesty, który dystansuje się od wizji edukacji i szkoły przede wszystkim funkcjonalnej, nastawionej na wyniki i efekty. Biesta postrzega szkołę jako przestrzeń, a przede wszystkim czas, dane nowej generacji na „spotkanie ze światem i na spotkanie ze sobą w relacji do świata”, na kształtowanie umiejętności „bycia w świecie”, z innymi i pośród innych ${ }^{4}$. Tę światocentryczną koncepcję uważa Biesta za przeciwieństwo ego-logicznego (ego-logical) paradygmatu życia i działania, wzmacnianego przez neoliberalną gospodarkę, reklamę (jesteś tego wart/a; należy ci się), ideologię rywalizacji (nie daj się wyprzedzić innym). Idea szkoły światocentrycznej zakłada, że świat i szkoła pozostają na siebie otwarte, sobą przeniknięte, ale że w tej wzajemnej relacji szkoła negocjuje swoją szczególność, to znaczy - nie jest poddana zasadzie nieustannego podnoszenia wyników, które można zmierzyć i przedstawić w rankingach. Światocentryczność wg Biesty polega na przygotowywaniu młodych ludzi do dojrzałego życia w świecie wolnych społeczeństw, w których zazwyczaj nie wszyscy mogą zrealizować wszystkie pragnienia i zdobyć to, co pożądane. To linia rozumowania

\footnotetext{
${ }^{3}$ Cytat z prezentacji PP Gerta Biesty Whatkind of societydoes the schoolneed? On qualityeducation in impatient Times, pokazywanej podczas konferencji TEPE: QUALITY TEACHERS AND QUALITY TEACHER EDUCATION: RESEARCH, POLICY AND PRACTICE, Kraków, maj 2019.

4 Myśl społeczna i edukacyjna Gerta Biesty wyrasta z filozofii i wizji społecznych Hannah Arendt, Paolo Freire'go, Petera Sloeterdijka, Jacquesa Ranciere'a, a pośrednio także z logiki wpisanej w dyskurs filozoficzny i polityczny Michela Foucautla i Jacquesa Derridy. Najogólniej rzecz ujmując, Biesta przeciwstawia się edukacji pojmowanej na sposób neoliberalny, jako procesu wytwórczego określonych dóbr (wyników, efektów) i wpisanej w mechanizmy zglobalizowanego, korporacyjnego społeczeństwa. Za naczelny cel edukacji Biesta uważa upodmiotowienie człowieka (obok socjalizacji i wykształcenia kompetencji) i wdrożenie młodych ludzi w arkana życia dojrzałego (grown-up), które ma polegać na świadomym, refleksyjnym, krytycznym podejściu do jednostkowych i grupowych pragnień i pożądań (czy to, czego pożądamy, jest warte, by tego pożądać?). Swój wielotomowy wywód na temat edukacji Biesta rozpisał (dotychczas) na książki: Beyond Learning (2006), Good Education in an Age of Measurement (2010), Learning Democracy in School and Society (2011), The Beautiful Risk of Education (2014), The Rediscovery of Teaching (2017), Obstinate Education: Reconnecting School and Society (2019), Educational Research: An Unorthodox Introduction (2020).
} 
Habermasa, mówiącego: „pamiętaj, że twoje życie rzadko jest tylko twoje”. Dlatego edukacja powinna skłaniać młodych ludzi do dialogu z ich wolnością i pragnieniami.

Według Rawlsa i Habermasa, filozofów patronujących temu tekstowi, wolne media mają podobne zadanie, bo budowanie dobra wspólnego nieodłącznie wiąże się z uświadamianiem tego, że żyjemy pośród innych, że dzielimy z nimi świat, państwo, miasto, miejscowość. Mamy różne poglądy i pragnienia, ale żyjemy obok siebie. Wspólnemu dobru sprzyja poznanie i zrozumienie, ale czasem także sprzeciw wobec zła, które spotyka nas i innych. Refleksja o roli mediów, o znaczeniu i miejscu niezależnego dziennikarstwa w życiu społeczeństw, to jedne z tych tematów, które przywracają szkole łączność ze światem i skłaniają do namysłu nad tym, jak i po co żyjemy. Wśród ludzi.

\section{Temat dziennikarski - trudna widowiskowość}

Temat mediów i dziennikarstwa często bywa - nomen omen - medialny, widowiskowy. Ta medialność jest jednak cokolwiek nieoczywista, nawet trudna, bo nie sprowadza się do audiowizualnej feerii - rzeczywistość redakcji, newsroomów, studiów telewizyjnych czy radiowych ma się nijak do scenerii i fabuł kina akcji. Tym, co sprawia, że chcemy oglądać filmy o zdarzeniach z życia dziennikarzy, redaktorów, szefów i właścicieli koncernów prasowych, kreatorów cyfrowego świata - jest bliskość życia, bliskość naszego życia. Jak wygląda ten świat, który transmituje i komentuje nam rzeczywistość? Ile jest prawdy w medialnym obrazie świata? Jak przebiega sporządzanie serwisów informacyjnych i co sprawia, że docierają do nas akurat te a nie inne treści? Ile kosztuje prawda, dlaczego kosztuje i kto decyduje się za nią płacić? Czy przekaz medialny to kreacja? I czy pragniemy jej, czy prawdy? Podobne pytania można mnożyć. Stawiają je mądre filmy, których twórcy chcą z nami rozmawiać o mediach w naszym życiu.

Filmy o pracy dziennikarzy nie powstają jak grzyby po deszczu. Jedną z podstawowych przyczyn umiarkowanego zainteresowania tym tematem producentów i twórców jest właśnie owa trudna widowiskowość. Ambitne zamiary rozwijania ekranowego dyskursu o dziennikarstwie owocują zazwyczaj kinem problemowym, dramatami obyczajowymi (czasem z wątkami sensacji czy kryminału) bądź politycznymi. Dla twórców takich filmów sprawa, temat, problem są często ważniejsze niż dochód, choć producenci dokładają starań, by obie te rzeczy szły w parze.

Idea wykorzystania filmu fabularnego $\mathrm{w}$ edukacji polonistycznej zakłada, że traktujemy język polski jako dziedzinę szerokiej edukacji kulturowej. Mądra refleksja o filmie nie może obejmować samego tematu ekranowej opowieści, powinna też dotyczyć sposobu, w jaki historia została opowiedziana. By użyć filologicznej frazy: ważne są plan treści i plan 
wyrażania, we wzajemnej relacji, w sprzężeniu zwrotnym. Jeśli oglądamy i omawiamy z młodzieżą film problemowy i zależy nam na interpretacji i wykorzystaniu dzieła jako inspiracji do rozmowy, dyskusji, pogłębionego komentarza, recenzji - powinniśmy - rzecz jasna - zdecydować się na lekturę całego utworu filmowego. Nie wyklucza to, oczywiście, analizy poszczególnych ujęć i scen (w pracy z filmem tego etapu nigdy nie pomijamy), przede wszystkim jednak umożliwia potraktowanie wypowiedzi ekranowej jako „wielkiej metafory” - jeśli film uprawnia do takiego spojrzenia.

\section{Fazy omawiania filmu}

Analizę i interpretację filmu najlepiej rozpocząć od zebrania pierwszych wrażeń, zarówno tych impresyjnych i emocjonalnych (film się podobał lub nie, jest dobry, słaby, znakomity, itp.), jak i tych możliwie skonceptualizowanych - zawierających pierwsze rozpoznania (film jest o...; porusza problem...). Ta pierwsza rekonstrukcja procesu autokomunikacji z dziełem powinna być punktem wyjścia do analizy, która będzie próbą weryfikacji świeżych ustaleń i konstatacji. Warto przeprowadzić ten etap od przywołania (z pamięci) ujęć i scen (także słów), które szczególnie mocno zapadły w pamięć odbiorców, lub które - w kontekście całości filmu i jego wymowy - wydają się kluczowe.

Rozmowę dobrze zacząć od argumentów na rzecz wyboru danego elementu dzieła. Jeśli jest taka możliwość - warto zacytować wskazane fragmenty - odtworzyć raz jeszcze, by uzupełnić czy zmodyfikować argumentację. Dobrym pomysłem jest rozpisywanie scen w formie mapy skojarzeń, na której pojawią się spostrzeżenia odnośnie zawartości kadrów i ujęć (np. punktów widzenia), tła muzycznego, sensu wypowiedzi bohaterów, klimatu, wymowy, relacji poszczególnych scen z innymi, itd. W tej fazie omawiania filmu nie od rzeczy będzie także zwrócić uwagę na tzw. strukturę sympatii i sprawdzić, które postacie zyskują akceptację i sympatię widza, co o tym decyduje, jak budowane jest nastawienie widza do uczestników zdarzeń tworzących akcję filmu.

Finałowa faza analizy i interpretacji filmu (nie tylko dydaktycznie zaaranżowanej) to ponowna rekonstrukcja - weryfikacja początkowych intuicji i rozpoznań, próba nadania znaczeń (o czym w istocie jest dla mnie ten film?) i wartościowania utworu (co sprawia, że cenię ten film lub uważam go za słaby; co nowego i na jaki temat mówi to dzieło ekranowe; jakim doświadczeniem było dla mnie oglądanie filmu?...).

Trzy wspomniane tu fazy omawiania filmu (trzy spojrzenia, podejścia do utworu filmowego) stanowią ogólny i uniwersalny schemat uporządkowanej dydaktycznie refleksji pofilmowej. Każde wartościowe dzieło ekranowe „wywołuje” wszakże konkretne sprawy, aktywuje wybrane zjawiska i dyskursy na ich temat, prowokuje do pytań, domniemań, stwierdzeń, podsuwa lub podważa punkty widzenia. Takie właśnie - konkretne, 
szczegółowe, wybrane klucze do analizy omawianych filmów będę proponował poniżej5.

Zaproponowane $\mathrm{w}$ artykule filmy fabularne można potraktować jako inspirację do podjęcia tematu dziennikarstwa i wolnych mediów lub jako swego rodzaju uwieńczenie klasowej refleksji o tych zjawiskach. Można je wykorzystać jako konteksty bądź teksty główne, samodzielnie bądź w relacji z tekstami literackimi czy publicystycznymi. W roli kontekstów można, rzecz jasna, wykorzystać fragmenty z pierwszej części tego artykułu. Tak postrzegam rolę tej partii tekstu.

Na potrzeby artykułu wybrałem kilka tytułów filmowych, najbardziej znaczących w tym obszarze kina współczesnego, który koncentruje się na zagadnieniu mediów i profesji dziennikarskiej. Przy wyborze filmów sugerowanych jako teksty kultury omawiane na lekcjach kierowałem się - jako jednym z kluczowych kryteriów - dzisiejszą ich dostępnością z legalnego źródła.

\section{Zawód: reporter}

Tytuł filmu Antonioniego z 1975 roku może uchodzić na gatunkowe określenie całej klasy dzieł ekranowych, o których tutaj mówimy. Przy czym paradoksalnie - właśnie tytuł, nie zaś sama fabuła, która w jedynie w sposób metaforyczny odnosi się do znaczenia włoskiej frazy Professione: reporter. Opowiedziana w filmie historia ma bowiem, w pierwszym rzędzie, wymiar kryminalny i psychologiczny. Utwór - jeden z najwybitniejszych w historii kina - już w czasach swego powstania uchodził za wymagający w odbiorze i nakręcony w kontrze do widowiskowego paradygmatu opowieści filmowej. Wyjątkowo więc może - jako jedyny w naszym przeglądzie - kwalifikuje się do fragmentarycznego wykorzystania - obejrzenia i interpretacji ostatniej sekwencji. Wrócę do niej w zakończeniu tego tekstu, decydując się na jego nieoczywiste zamknięcie.

Wszyscy ludzie prezydenta (USA, 1976, reż. Alan Pakula, film dostępny odpłatnie na platformie rakuten.tv.pl) to z kolei mistrzowsko zrealizowany thriller polityczny przedstawiający ekranową wersją zdarzeń z 1972 i 73 roku, które później doprowadziły do upadku prezydenta USA, Richarda Nixona, w szczególności zaś odtwarzający nić dziennikarskiego śledztwa, dzięki któremu ta bulwersująca sprawa wyszła na jaw. Nie streszczam

${ }^{5}$ Pojawiające się często w tym tekście pojęcie „analizy filmu” nie powinno działać odstraszająco. Pisząc o „analizie”, mam bowiem na myśli świadomie inicjowany proces zatrzymywania się przy wybranych fragmentach i elementach filmu, które zdają się mieć istotne znaczenie i mocno oddziałują na widza. Jak piszą Jacques Aumont i Michel Marie, „nie istnieje (...) żadna uniwersalna metoda analizy filmów” (wspomniany przeze mnie wyżej schemat nie jest metodą analizy w sensie wykorzystania konkretnych narzędzi metodologicznych). Francuscy filmoznawcy uważają, iż „analityczna recepcja dzieła filmowego zaczyna się (...) w chwili, gdy decydujemy się na podział całości w celu wyodrębnienia poszczególnych elementów. Koncentrujemy się wówczas na określonym momencie, kadrze, jego części lub osobnej scenie" (Aumont, Marie 2011, 14, 22). Jest to więc, po prostu, zainteresowanie szczegółem, właściwe nie tylko badaczowi czy krytykowi, ale także widzowi, zwłaszcza wrażliwemu, zainteresowanemu kinem i skoremu do rozmów o filmie. Podsumowujący komentarz na temat wymowy filmu, jego sensu (bądź sensów), także gatunku czy wartości jest interpretacją, najlepiej jeśli wspartą na oglądzie szczegółów, czyli analizie. Takie analizy i interpretacje przydarzają się wielu widzom, także młodym, choć nie używają oni tych określeń. 
tu fabuły, bowiem o samej sprawie, jak i filmie, można sporo przeczytać w Internecie. Skupię się na sugestiach działań analitycznych i propozycjach tematów do rozważenia.

Ponieważ lwia część fabuły obejmuje rozmowy dziennikarzy z ich szefami i informatorami, oglądanie ponaddwugodzinnego filmu i śledzenie wysiłków obu bohaterów może być wymagające dla współczesnego młodego widza. Jednak tylko stopniowe i uważne zagłębianie się w penetrowany przez obu dziennikarzy świat pozwoli widzowi odczuć dramaturgię zdarzeń i zrozumieć dylematy bohaterów. Film ma przemyślaną kompozycję, która zakłada przeplatanie dłuższych fragmentów rozmów i wywiadów scenami wnoszącymi napięcie (spotkania $\mathrm{z}$ informatorem $\mathrm{w}$ podziemnym garażu) lub dynamikę (ujęcia dynamicznie uderzających czcionek maszyn drukarskich; rozmowa bohaterów poprzez pisanie na maszynie). Twórcy filmu operują kontrastem jasność - ciemność, obie te kategorie nasycając symboliką, w kilku ujęciach z lotu ptaka przywołują motyw labiryntu (biblioteka Kongresu, miasto $\mathrm{w}$ nocy). W proponowany wcześniej, trójfazowy schemat omawiania filmu warto wpleść sugerowane niżej kwestie i zagadnienia. Wymieniam je $\mathrm{w}$ trzech blokach (podobnie $\mathrm{w}$ przypadku pozostałych filmów), choć mam świadomość, że opowieść i forma nierozerwalnie się splatają, więc w pofilmowej refleksji warto mówić (pisać) o nich łącznie.

Analiza świata przedstawionego / fabuły.

- W trakcie rozwoju zdarzeń Bob Woodward coraz częściej się dziwi. Co zdumiewa dziennikarza w miarę posuwania się śledztwa? Dlaczego?

- Jak na kolejne ustalenia śledztwa reaguje kierownictwo gazety? Jakie są przyczyny tych reakcji?

- Kiedy opowieść dziennikarza staje się wiarygodna? Co sprawia, że rekonstruowana historia nabiera wagi? Bohaterowie mówią o tym w kilku scenach.

- W filmie kilkakrotnie padają słowa: „To niebezpieczna sprawa dla tej gazety". Na czym polega niebezpieczeństwo? Skąd i dlaczego może nadejść?

- W filmie jest scena, w której Bob Woodward zaczyna odczuwać lęk. Dlaczego dzieje się to właśnie w tym momencie? Czego obawia się dziennikarz?

- Oceń postępowanie dwójki dziennikarzy. Czy spryt i przebiegłość idą za daleko? Dlaczego tak lub nie?

- W trakcie jednej z rozmów redakcyjnych padają słowa szefa redakcji: „Kochamy ten kraj. I nie chcemy go zniszczyć!” Czy to akt obrony, chęć usprawiedliwienia, a może forma otuchy dla dziennikarzy?

- Jak rozumiesz scenę rozmowy Woodwarda i Bernsteina poprzez pisanie na maszynie przy dźwiękach muzyki Haendla? Co może symbolizować stukot maszyny, co głośna, podniosła muzyka? 
- W kulminacyjnym momencie fabuły Ben Bradlee, redaktor naczelny „The Washington Post”, wypowiada słowa: „Jeżeli coś nas trzyma przy życiu to pierwszy artykuł Konstytucji, wolność słowa i może przyszłość tego kraju". Co mówią te słowa o motywacji dziennikarzy w staraniach o ujawnienie prawdy o działaniach władzy?

- Jak rozumiesz finałową sekwencję, na którą składają się: migawki z zaprzysiężenia prezydenta, strzały armatnie, ujęcia dziennikarzy zapamiętale piszących artykuły, wiadomości drukowane przez telefax?

Analiza formalna

- Kilka ujęć z lotu ptaka (biblioteka Kongresu, miasto w nocy) nawiązuje do motywu labiryntu. Jak wytłumaczyć obecność tego motywu w filmowej historii?

- Od pierwszej sceny twórcy filmu operują motywem ciemności (wyciemnienia). Jaką rolę pełni w filmie ten motyw, do jakich znaczeń odsyła? Zwróć uwagę na muzykę, która towarzyszy tym scenom i ujęciom.

- Kilkakrotnie pojawia się w filmie podzielony kadr - widać w nim dwie osobne sytuacje. Jaką informację otrzymuje widz dzięki temu?

- Zwróć uwagę na środki filmowe, które tworzą atmosferę zagrożenia.

- Które z pojęć lepiej określa kompozycję filmu: monotonia czy rytmiczność? Wyjaśnij, odwołując się do konkretnych scen / sekwencji.

„Wielka metafora”

- O czym właściwie jest ten film: o nadużyciach władzy, o roli wolnej prasy, o czymś jeszcze? Uzasadnij swoją koncepcję interpretacji, przywołując wybrane elementy filmu.

- Optymizm czy pesymizm? Jaka jest, w gruncie rzeczy, wymowa filmu? Co o tym decyduje?

Fakty i akty (tytuł oryginalny Wag the Dog, USA 1997, reż. Barry Levinson), to komediodramat o tematyce politycznej z początków ery cyfrowej, który znalazł się w tym zestawieniu na prawach wyjątku. Film nie jest bowiem legalnie dostępny w ofercie dystrybutorów płyt DVD ani platform cyfrowych, mimo że był obecny na ekranach polskich kin w rok po premierze. Decyduje się jednak na krótką prezentację tego utworu, bo odznacza się błyskotliwym scenariuszem, widowiskową fabułą i niebanalnymi spostrzeżeniami na temat roli tzw. postprawdy i fake newsów w życiu społeczeństw poddanych działaniu mediów.

Główną osią fabuły jest intryga zmierzająca do odwrócenia uwagi opinii publicznej od aktu molestowania seksualnego nastolatki, którego dopuścił się urzędujący prezydent tuż przed wyborami. Doradcy prezydenta wynajmują specjalistę od marketingu politycznego, by ten uruchomił medialną akcję niwelującą propagandowe straty po skandalu w Białym Domu. Wynajęty spindoctor zatrudnia z kolei hollywoodzkiego producenta, który 
wymyśla i produkuje karkołomną medialną historię o wojnie w Albanii, wojnie, której nie ma. Rusza telewizyjna i prasowa machina...

W filmie Levinsona nie występuje żaden niezależny i uczciwy dziennikarz, pozornie ta opowieść nie tego dotyczy. Etos wolnego, rzetelnego dziennikarstwa, jest tu jednak obecny jako zaprzeczenie tego, co robią bohaterowie, jako odruchowa reakcja widza, który ma prawo z niedowierzaniem kręcić głową i buntować się $\mathrm{w}$ imię własnych racji. Zręcznym pociągnięciem autorów filmu jest brak pozytywnej postaci, jakby to sam widz, z konieczności, musiał przyjąć rolę surowego krytyka działań kreatorów medialnej (?) rzeczywistości. Biorąc pod uwagę datę powstania Faktów i aktów, trzeba przyznać rację recenzentowi, który pisze, iż „film Barry'ego Levinsona okazał się (...) niepokojąco profetyczny" ${ }^{6}$.

Analiza świata przedstawionego / fabuły.

- $\quad$ Z jakich pobudek działa wynajęty przez otoczenie prezydenta specjalista od marketingu politycznego, Conrad Brean? Zwróć uwagę na jego wypowiedzi, zachowania i determinację w działaniu.

- Co wiemy o motywach działania producenta, Stanleya Mottsa? Które sceny przynoszą najwięcej informacji na ten temat?

- Dwaj główni bohaterowie filmu (wymienieni powyżej) często w rozmowach nazywają istotę swojego działania, np. „Stworzymy pozory”; „Produkcja iluzji”; „Babramy się w gównie”; „To polityka najwyższych lotów”; „Tworzymy historię”; „Nie było wojny. Szczegół”; „To będzie arcydzieło"; „Show musi trwać”. Czy Brean i Motts doceniają siebie, czy mają świadomość moralnej jakości swoich działań?

- Które zdarzenia filmowej fabuły najbardziej zaskakują? Dlaczego?

- W filmie pojawiają się epizodycznie postacie dziennikarzy. Jaki portret tego środowiska pokazano w Faktach i aktach?

Analiza formalna

- Tło muzyczne to pogodna, rytmiczna, melodyjna kompozycja w typie łagodnego country rocka. Muzyka wypełnia znaczną część opowieści. Co wnosi do filmu, jak kształtuje wymowę zdarzeń?

- Satyra polityczna, tragikomedia, groteska - które z tych określeń gatunkowych najlepiej pasuje do filmu Levinsona? Uzasadnij swoją opinię.

„Wielka metafora”

- „Widziałeś? Prawdziwe łzy” - mówi Stanley Motts, oglądając reakcję publiczności na wykonanie piosenki stanowiącej część akcji propagandowej. Na widok finałowej uroczystości wojskowej dodaje: „Mistyfikacja jest szczera”. O jakim zjawisku społecznym mówi bohater?

${ }^{6}$ Fakty i akty (Wag the Dog), http://zyciewkinie.pl/post/8325 (dostęp: 10.10.2020). 
- Dlaczego ginie Stanley Motts? Jakiej symboliki możemy się dopatrzyć w finale jego losu i sposobie, w jaki się o tym dowiadujemy?

- Jak rozumiesz oryginalny tytuł filmu? Nawiązuje on do swoistego motta opowieści, które brzmi:

Why does the dog wag its tail?

Because a dog is smarter than its tail.

If the tail were smarter, it would wag the dog.

Dlaczego pies macha ogonem?

Ponieważ pies jest sprytniejszy niż ogon.

Jeśli ogon byłby sprytniejszy, to on machałby psem.

Kto w filmie jest ogonem, kto psem?

Spotlight (2015, USA, reż. Tom McCarthy) to dramat obyczajowy, który jest rekonstrukcją zdarzeń prowadzących do publikacji serii artykułów na temat molestowania seksualnego dzieci przez księży katolickich w Bostonie i postawy kardynała Bernarda Lawa w tej sprawie. Fabuła filmu dokładnie odzwierciedla sekwencję wypadków, uruchomioną przez dziennikarzy śledczych z grupy Spotlight, działającej w obrębie redakcji dziennika „The Boston Globe". Film, nagrodzony dwoma Oscarami (w kategoriach: najlepszy film i najlepszy scenariusz oryginalny), jest zbudowany na niemal identycznym schemacie fabularnym, który zastosowano we Wszystkich ludziach prezydenta. W sferze języka filmowego pozostaje nieco mniej wyrafinowany niż wspomniany obraz Alana Pakuli, odznacza się dość jednostajną akcją i nastrojem wyciszenia. Jest tyleż zapisem dziennikarskiego śledztwa, ile wewnętrznego dramatu ludzi dotkniętym molestowaniem i tych, którzy tę historię odkrywają i podają do wiadomości publicznej. Film jest dostępny na płytach DVD w ofercie polskich dystrybutorów.

Analiza świata przedstawionego / fabuły.

- Akcja filmu toczy się na przełomie 2001 i 2002 roku. Pierwsza sekwencja dotyczy jednak zdarzenia z roku 1976. Jakie znaczenie dla dramaturgii utworu ma ten fragment, co mówi widzowi? Zastanów się, z czyjej perspektywy śledzimy otwierające film zdarzenie.

- Początkowo redakcja gazety jest podzielona w sprawie publikacji materiałów obciążających księży. Dlaczego? Jakie przeszkody w ujawnieniu prawdy dostrzegają dziennikarze?

- Redaktor naczelny, Marty Baron, stwierdza w jednej z rozmów, iż „gazeta najlepiej spełnia obowiązki, gdy występuje sama”. Jak rozumiesz te słowa, o jaką „samotność” chodzi?

- Które słowa i deklaracje bohaterów najlepiej oddają sens ich pracy, opisują misję, do której czują się powołani? Zacytuj i skomentuj kilka wypowiedzi wybranych postaci.

- W jednej ze scen szef grupy dziennikarzy, Walter „Robby” Robinson, wznosi toast ze znajomym, mówiąc: „Za Boston”. Co szczególnego 
Zawód: reporter. Filmowy dyskurs o dziennikarstwie na lekcjach języka polskiego

jest $\mathrm{w}$ tym mieście, według ocen i wypowiedzi różnych postaci filmu?

- W jednej z rozmów redakcyjnych Robinson deklaruje, że nie chce szkodzić księżom i Kościołowi, lecz „dopaść system”. Dlaczego decyduje się zwolnić tempo działania i odwleka publikację materiałów? Weź pod uwagę przeszłość bohatera, o której w trakcie filmu dowiadują się jego współpracownicy.

- Kiedy w końcu dochodzi do publikacji artykułów o molestowaniu? Co musiało się wydarzyć, żeby prawda ujrzała światło dzienne?

- Zjakich pobudek działają dziennikarze grupy Spotlight? Przypomnij sobie sceny, które o tym informują lub dają widzowi do myślenia (np. spacer jednego $\mathrm{z}$ dziennikarzy $\mathrm{w}$ okolice pobliskiego domu opieki).

Analiza formalna

- Jedna ze scen filmu pokazuje w dynamicznych ujęciach pracujące z zawrotną szybkością maszyny drukarskie. Jak rozumiesz tę scenę, jakie symboliczne znaczenie można jej nadać?

- Którym scenom z filmu (innym niż wspomniana powyżej) można przypisać głębsze, np. symboliczne znaczenie? Wymień choć jedną i uzasadnij swój wybór.

- Jak określisz muzykę w filmie Spotlight - jako wyrazistą, dyskretną, ilustracyjną, towarzyszącą, może jeszcze inaczej? Jaką rolę pełni, co wprowadza, w jaki sposób oddziałuje na widza?

- Głównym składnikiem fabuły i motorem akcji są w filmie rozmowy. Czy twórcy filmu uniknęli monotonii, efektu zmęczenia widza? Jeśli tak - dzięki czemu? Jeśli nie - jak można było tego uniknąć?

„Wielka metafora”

- W jednej z rozmów redaktor naczelny „The Boston Globe” wypowiada słowa: „Ludzie potrzebują sacrum”. Jaki związek mają te słowa z historią opowiedzianą w filmie? Czy Spotlight można uznać za głos w sprawie tych potrzeb egzystencjalnych? Rozwiń swoją wypowiedź, przywołaj fragmenty filmu.

- W opiniach o filmie Spotlight przeważały głosy, że jest to opowieść o potędze niezależnego dziennikarstwa. Czego wymagają od dziennikarzy owe: potęga i niezależność? W odpowiedzi powołaj się na wybrane sceny i ujęcia.

Czwarta władza (The Post, USA, 2017, reż. Steven Spielberg) to film dostępny w ofercie polskich dystrybutorów DVD. Ten dramat obyczajowy z elementami thrillera politycznego przenosi nas do tej samej redakcji, w której gościliśmy w przypadku Wszystkich ludzi prezydenta. Dzięki Spielbergowi jesteśmy tam niecały rok wcześniej (1971), kiedy redakcja, właścicielka gazety i zarząd stoją przed dylematem dotyczącym publikacji 
tajnych materiałów rządowych na temat polityki zagranicznej USA od wczesnych lat 50. Reporterzy „The Washington Post” dostają do rąk sekretny raport ministerialny sprzed kilku lat, który już wcześniej dotarł do dziennikarzy „New York Timesa”. Dowiadując się o zamiarze publikacji tajnych materiałów, kompromitujących władze USA, prezydent i rząd wszczynają działania zmierzające do zakazu upowszechnienia raportu. Mimo korzystnej dla rządu decyzji sądu pierwszej instancji i groźby poważnych konsekwencji, właścicielka gazety, Katherine Graham, wspierana przez redaktora naczelnego (Bena Bradlee'go) decyduje się na publikację materiałów...

Kino amerykańskie ma długie i dobre tradycje w produkcji dramatów obyczajowo-politycznych. Wszystkie one koncentrują się wokół zagadnień transparentności poczynań polityków, przestrzegania reguł demokracji spisanych w Konstytucji i wolności mediów. Nie przypadkiem więc omawiam w tym artykule głównie filmy zza Atlantyku. Czwarta władza podtrzymuje tę dobrą tradycję, posługując się tym, co w kinie amerykańskim efektowne i rozpoznawalne: sprawną, dynamiczną narracją, niewymuszoną symboliką, klarowną kompozycją fabuły. Pewien naddatek patosu przyjmujemy więc z całym dobrodziejstwem inwentarza.

Analiza świata przedstawionego / fabuły.

- W pierwszej sekwencji filmu (epizod z wojny wietnamskiej) zaskakującym elementem świata przedstawionego jest maszyna do pisania. Jakie oczekiwania widza wywołuje ten rekwizyt?

- Sekretarz obrony, McNamara w krótkim odstępie czasu (w trakcie lotu i po wylądowaniu) wypowiada się o wojnie w Wietnamie. Co zaskakuje $\mathrm{w}$ jego wypowiedziach? W których scenach pojawi się echo tego zachowania?

- Dlaczego szef redakcji The Washington Post" chce zdobyć materiały będące już w posiadaniu „New York Timesa”?

- Czego dotyczy gorzka rozmowa Katharine Graham z długoletnim przyjacielem, byłym sekretarzem obrony, McNamarą? Co zarzuca mu właścicielka gazety? Jak broni się McNamara?

- Kilka scen filmu pokazuje narady, dyskusje i kłótnie wokół dylematu: publikować tajny raport czy nie? Jakie padają argumenty, kto chce drukować, kto oponuje? Dlaczego?

- Wiedząc o kłopotach „New York Timesa”, naczelny „The Washington Post” mówi: „Ich klęska będzie naszą klęską”. Co oznaczają te słowa, o jakiej postawie świadczą? (Trzeba wiedzieć, że na amerykańskiej scenie prasowej obie gazety konkurują ze sobą).

- Jakie jest znaczenie sceny pokazującej drogę materiału do druku? Jak oddziałują na widza ujęcia kolejnych etapów wędrówki tekstu do maszyn drukarskich?

- Co sprawia, że Katharine Graham podejmuje decyzję o druku materiałów? Które argumenty przeważają: odpowiedzialność wobec 
redakcji i pracowników gazety, wobec społeczeństwa, odpowiedzialność za siebie i rodzinę, troska o żołnierzy amerykańskich w Wietnamie, wierność misji gazety zapisanej w jej statucie? Jaką rolę $\mathrm{w}$ podjęciu decyzji odgrywa świadomość niedoceniania Katharine jako kobiety na czele wielkiej firmy?

- Co sprawia, że przed posiedzeniem Sądu Najwyższego szefowie konkurencyjnych redakcji ściskają sobie dłonie?

Analiza formalna

- Jedna z kulminacyjnych scen filmu przedstawia telefoniczną rozmowę Katharine Graham ze współpracownikami, poprzedzającą podjęcie decyzji. Czemu służą zastosowane tu środki filmowe: długie ujęcia twarzy, niepokojąca muzyka w tle, najazd kamery? Co wyraża twarz bohaterki?

- Twórcy filmu kilkakrotnie stosują montaż równoległy, sposób narracji pokazujący dwa równocześnie rozgrywające się wątki (np. narada i wędrówka materiału do druku). Przypomnij sobie więcej takich fragmentów. Co zyskuje film dzięki takiej postaci narracji?

- Kiedy maszyny drukarskie w końcu ruszają, redakcyjne stoły drżą. Jak rozumiesz tę scenę?

- Dzień po publikacji Ben Bradlee przynosi do gabinetu właścicielki egzemplarze innych amerykańskich gazet i symbolicznie rozkłada je na stole. Jak interpretujesz te ujęcia?

- Po wysłuchaniu stron przed Sądem Najwyższym Katharine Graham schodzi po schodach budynku wśród tłumów wspierających ją demonstrantów. Większość z nich to kobiety. Jak interpretujesz tę scenę?

„Wielka metafora”

- W filmie Spielberga pada wiele ważnych słów i wypowiedzi. Wybierz najważniejszą, według ciebie, wypowiedź z tych niżej zacytowanych lub przypomnij inną. Zinterpretuj jej sens i omów wagę tych słów.

- „Musimy ich kontrolować. Kto ich rozliczy, jeśli nie my?” (redaktor naczelny Ben Bradlee)

- „Jeżeli to opublikujemy, przestaniemy istnieć." (Prezes Zarządu) „Jeżeli to rząd ma nam dyktować, co mamy publikować, to już przestaliśmy istnieć." (Ben Bradlee)

- „Jedynym sposobem, by utrzymać prawo do publikacji, jest publikować." (Ben Bradlee)

- „Prasa ma służyć rządzonym, nie rządzącym.” (fragment uzasadnienia wyroku Sądu Najwyższego).

- O czym dla Ciebie jest ten film: o roli wolnych mediów w demokracji? O pozycji kobiet $\mathrm{w}$ hierarchii społecznej, zawodowej? 
O roli niezależnego sądownictwa w państwach demokratycznych? O odwadze dziennikarzy?

Obywatel Jones (Mr Jones, Wielka Brytania, Polska, Ukraina, 2019, reż. Agnieszka Holland), podobnie jak większość omawianych w tym tekście filmów, wykorzystuje fabularnie autentyczne wydarzenia. Tym razem poznajemy historię Garetha Jonesa, młodego Walijczyka, dziennikarza, który na początku lat 30. XX wieku był doradcą komisji spraw zagranicznych parlamentu brytyjskiego i byłego premiera, Davida Lloyda George’a. Jones, zainteresowany sytuacją w Związku Sowieckim (ZSRR), wyrusza w podróż do Moskwy, by zorientować się, skąd Sowieci mają pieniądze na inwestycje w obliczu doniesień o głodzie milionów ludzi w ich kraju. Nie będąc już doradcą Lloyda George'a, podróżuje jako dziennikarz, wkrótce podejmując $\mathrm{z}$ Moskwy wyprawę na Ukrainę ( $\mathrm{w}$ istocie wraca tam, gdzie mieszkał kilka lat z matką, nauczycielką dzieci walijskiego przemysłowca, inwestującego w okolicach dzisiejszego Doniecka). Podróż ta zaważy w decydujący sposób na życiu Garetha Jonesa...

Film Agnieszki Holland stosunkowo wiernie odtwarza historię eskapady młodego Walijczyka, włączając $\mathrm{w}$ obręb fabuły postać i dzieło George'a Orwella, inspirującego się w trakcie pisania Folwarku zwierzęcego doniesieniami Jonesa. Omówienie filmu z klasą niewątpliwie wymagać będzie poznania kontekstu historycznego, co - wobec mnogości materiałów obecnych w sieci - nie stanowi większego wyzwania.

Analiza świata przedstawionego / fabuły.

- „Tylko ja mówię Panu prawdę” - zwraca się do Lloyda George’a bohater filmu, po utracie funkcji doradcy. Jakie motywacje kierują tymi, którzy tej prawdy nie ujawniają? Dlaczego prawdę odrzuca sam były premier?

- „Nie jest pan dziennikarzem, pan chciałby nim być” - mówi Jonesowi urzędniczka w ambasadzie sowieckiej, dowiadując się o braku jego zatrudnienia $\mathrm{w}$ jakiejkolwiek redakcji. Co - według samego Jonesa - decyduje o pełnieniu roli dziennikarza? Jakie jest jego powołanie? Weź pod uwagę postawę bohatera i jego rozmowy, np. z Adą Brooks.

- Jones podaje się za doradcę Lloyda George'a. Fałszuje jego list, okłamuje sowieckiego ministra Litwinowa. Czy motywacje jego działania usprawiedliwiają to oszustwo? Tak, nie, dlaczego?

- Z jakimi przejawami państwa opresyjnego spotyka się Jones w Moskwie i w trakcie swej podróży po Ukrainie? Jakie wartości gwałci władza sowiecka?

- „Najlepsze party w mieści tylko u Duranty’ego” - mówi jeden z obcokrajowców spotkany w hotelu. Co przyjęcie u amerykańskiego dziennikarza mówi o jego pozycji w Moskwie, życiowej postawie, hierarchii wartości? 
- Jak w filmie sportretowano władze sowieckie, ich strategie działania? Jaka jest sytuacja ludzi władzy w porównaniu do zwykłych mieszkańców?

- Gareth Jones uważa Waltera Duranty'ego za część „politycznego spisku". Czyj to spisek i co ma na celu?

- Jakim doświadczeniem jest dla Jonesa podróż po mroźnej Ukrainie? Czego się dowiaduje o rzeczywistości w Związku Sowieckim?

- Przedstaw dylemat Jonesa, przed którym bohater staje po powrocie z Ukrainy. Przypomnij racje Lloyda George'a, Orwella i samego Garetha. Jakie wyjście z sytuacji wybiera Jones, co zyskuje, co traci? Jakie znaczenie ma jego decyzja dla innych?

Analiza formalna

- W filmie regularnie powracają ujęcia George'a Orwella piszącego Folwark zwierzęcy. Jaka jest ich funkcja, czym są te sceny w stosunku do głównego wątku filmowej opowieści?

- W sekwencji przyjęcia u Duranty'ego pojawiają się deformacje obrazu i przyśpieszone tempo zdjęć. Jaką wymowę nadają te zabiegi całej sekwencji?

- Sekwencja podróży po Ukrainie utrzymana jest w niemal czarno-białej tonacji. Jakie znaczenie nadaje temu fragmentowi taka barwa zdjęć? Jak rozumiesz ten filmowy zabieg twórców filmu?

- W sekwencji ukraińskiej podróży Jonesa pojawia się motyw pomarańczy, kontrastującej swą barwą z szarym otoczeniem. Jak odczytujesz symbolikę tego owocu $\mathrm{w}$ filmie? Przywołaj z pamięci inne symboliczne elementy filmowych kadrów.

- Agnieszka Holland kilkakrotnie stosuje w tym filmie zestawienia kontrastowych scen. Postaraj się przywołać z pamięci choć jedno takie zestawienie. Czemu one służą?

„Wielka metafora”

- „Co każe panu tu siedzieć i kłamać dla nich?” - pyta Gareth Jones Waltera Duranty'ego po powrocie z Ukrainy. Przedstaw motywacje Amerykanina i innych postaci, które zachowują się w sposób niezrozumiały dla walijskiego dziennikarza.

- W rozmowie z Adą Brooks główny bohater stwierdza: „Chcę tylko ustalić prawdę (...). Najszlachetniejsze jest dziennikarstwo relacjonujące nawet niewygodne fakty. Bezstronnie." Czy słowa Jonesa wytrzymują próbę czasu, czy powinny być dziennikarskim drogowskazem także dzisiaj?

- W scenie w Moskwie z okazji uznania ZSRR przez USA słychać komentarz spoza kadru, mówiący o upodobnieniu ludzi i świń. Jak rozumiesz tę scenę? Kim w tekście Orwella są świnie, zwierzęta, ludzie? 
Zawód: reporter (Professione: reporter, tytuł angielski: The Passenger, Francja, Hiszpania, Włochy, 1975, reż. Michelangelo Antonioni) to dramat w stylu kina noir (czarnego kryminału), który znalazł się tu na prawach wspomnianej uprzednio puenty. Wymogi szkolnej praktyki sugerują (jeśli w ogóle omawiać ten film) wykorzystanie końcowej sekwencji tego trudnego w odbiorze utworu (choć z wybraną grupą młodzieży można się pokusić o obejrzenie całości). Nie jest to film o dziennikarzach i dziennikarstwie, choć jego głównym bohaterem jest reporter. Może jednak prowokować pytania w rodzaju: kim właściwie jest reporter, czy po trochu nie jest nim każdy z nas? W jakim stopniu poznajemy świat, obserwując go, ile prawdy odkrywa nam powierzchnia rzeczywistości? I w końcu: Czy poznawanie i opisywanie świata nie jest właściwie poznawaniem siebie samego? Czy sami nie jesteśmy dla siebie zagadką na podobieństwo otaczającego świata?

W zastępstwie własnego tekstu posłużę się w zakończeniu obszernym fragmentem frapującej recenzji Marii Kornatowskiej z 1975 roku.

Reporter (Jack Nicholson) kręci film dokumentalny o jednej z afrykańskich republik. Czuje się jednak bezradny wobec obcej, nieprzeniknionej rzeczywistości, która go otacza, której mechanizmów nie potrafi pojąć. Pragnie zmienić osobowość, odzyskać wolność przez wcielenie się w inną rolę, korzystając więc ze śmierci w afrykańskim hotelu pewnego biznesmena, zamienia paszporty i przyjmuje nową postać. Cudowna wolność okazuje się wszakże pozorem. Życie bohatera przeistacza się w ciągłą bezsensowną ucieczką. Biznesmen sprzedawał broń partyzantom, naraził się więc rządowi. Osaczony ze wszystkich stron, wciągnięty w pułapkę cudzego losu, reporter prawdopodobnie ginie z rąk tajemniczych morderców, będących na usługach reżimu. W poprzedzającej śmierć ucieczce towarzyszy mu młoda Hiszpanka, studentka architektury (Maria Schneider) - której właściwa rola nie zostaje do końca wytłumaczona. Niewykluczone, że i ona działa w porozumieniu $\mathrm{z}$ mordercami.

Los bohatera jest od początku przypieczętowany i fatalistycznie zmierza ku swemu spełnieniu. Nieubłagane fatum, od którego nie ma ucieczki, realizuje się przez pozorną przypadkowość. Rzeczywistość ujawnia swe wieloznaczne, niepojęte, a tym samym absurdalne oblicze. Reporter nie jest w stanie ani zrozumieć, ani rozerwać sieci, w którą sam się uwikłał.

W żadnym z dotychczasowych filmów katastrofizm Antonioniego nie uwidocznił się $\mathrm{z}$ taką siłą. Elementy dramatu sensacyjnego i politycznego stanowią jedynie dymną zasłonę. Potęgują bowiem poczucie nieprzeniknioności świata, wyobcowania i osaczenia bohatera, który nie może już nic owemu światu przeciwstawić. Jest biernym, milczącym, „ślepym” obserwatorem, który nie potrafi nawet być naprawdę wolnym. Trudno zgadnąć, czy jego ucieczka od siebie stanowi próbę buntu, czy też samobójstwa.

Tym razem Antonioni zakwestionował wszystko: sens życia, sens związków między ludźmi i sens swojej sztuki: sztuki obrazu-świadectwa (Kornatowska 1975).

A może reporter z filmu Antonioniego posunął się za daleko, wdzierając się do świata, który opisywał, stając się bohaterem prawdziwego, nieudawanego thrillera? Może pomylił role? A może strony? Czyż rolą dziennikarza nie jest stać po dobrej stronie, swoją pracą przyczyniać się do dobra 
Zawód: reporter. Filmowy dyskurs o dziennikarstwie na lekcjach języka polskiego

wspólnego? Czasem rozpoznanie owego dobra nie jest łatwe, tym bardziej opowiedzenie się za nim, czasem to kosztuje. Ale odrzucenie tych zasad kosztuje więcej nas wszystkich.

\section{Bibliografia}

Aumont Jacques, Marie Michel, 2011, Analiza filmu, Zawadzka M. (przeł.), Warszawa.

Foessel Michael, 2016, Powołanie filozofii. Krytyka i komunikacja. Z Jurgenem Habermasem rozmawia Michael Foessel, grudzień 2016, https://www.miesiecznik. znak.com.pl/powolanie-filozofi-krytyka-i-komunikacja (dostęp: 10.10.2020).

Kapuściński Ryszard, 2003, Autoportret reportera, Strączek K. (wybór i wstęp), Kraków.

Kornatowska Maria, 1975, Zawód: reporter, „FILM” nr 15 (115).

Pisarek Walery (red.), 2006, Słownik terminologii medialnej, Kraków.

Rawls John, 1994, Teoria sprawiedliwości, Panufnik M., Pasek J., Romaniuk A. (przeł.), Warszawa.

Skrzypczak Józef (red.), 1999, Popularna encyklopedia mass mediów, Poznań.

Wróbel Szymon, 2016, Pożytek z Jurgena Habermasa, https://www.miesiecznik. znak.com.pl/pozytek-z-jurgena-habermasa (dostęp: 10.10.2020).

\section{O Autorze}

Witold Bobiński - profesor na Wydziale Polonistyki Uniwersytetu Jagiellońskiego i pracownikiem Katedry Polonistycznej Edukacji Nauczycielskiej. Pracę na uczelni rozpoczął jako nauczyciel polonista z kilkunastoletnim stażem i autor podręczników historii i języka polskiego. Samodzielnie i we współautorstwie opracował do dzisiaj dwadzieścia podręczników wydanych w siedmiu seriach. Był ekspertem MEN w pracach nad podstawą programową z roku 2009, od 2015 roku jest wykładowcą Szkoły Edukacji Polsko-Amerykańskiej Fundacji Wolności i Uniwersytetu Warszawskiego. Pasjonuje się wykorzystaniem filmu fabularnego w edukacji humanistycznej, o czym traktują rozprawy: Teksty w lustrze ekranu. Okołofilmowa strategia kształcenia literacko-kulturowego (Kraków 2011), Wykształcić widza. Sztuka oglądania w edukacji polonistycznej (Kraków 2016). Przygotowuje książkę o redefinicji celów i metod nauczania języka polskiego zgodnie $\mathrm{z}$ duchem idei ekologii edukacji. 
